\title{
Academic Freedom in the Heartland: Rights Consciousness and the United States Supreme Court
}

\author{
Darren Botello-Samson ${ }^{1}$ \\ ${ }^{1}$ Department of History, Philosophy, and Social Sciences, Pittsburg State University, Pittsburg, KS, USA \\ Correspondence: Darren Botello-Samson, Department of History, Philosophy, and Social Sciences, Pittsburg \\ State University, 1701 S. Broadway, Pittsburg, KS, USA 66762. Tel: 1-620-235-4334. E-mail: \\ dbotello-samson@pittstate.edu
}

Received: August 19, 2015 Accepted: August 28, 2015 Online Published: November 29, 2015

doi:10.5539/jpl.v8n4p208

URL: http://dx.doi.org/10.5539/jpl.v8n4p208

\begin{abstract}
In late 2013, the Kansas Board of Regents proposed a social media policy, a policy which the board eventually unanimously approved. The policy authorized "the chief executive officer of a state university...to suspend, dismiss or terminate from employment any faculty or staff member who makes improper use of social media." A strong and unified condemnation of the policy followed, led primarily by the faculty of those institutions and their various faculty governance organizations. This conflict between the free speech rights of academics and the governing authority of government and university administrations in the state of Kansas was neither the first nor last such conflict; U.S. courts had already established a doctrine over the free speech rights of public employees. Therefore, this conflict presents an opportunity to observe how the judicial establishment and definition of rights affects subsequent political conflict and discourse. The conflict over the social media policy adopted by the Kansas Board of Regents raises questions of whether the established judicial articulations of free speech in an academic setting shaped the efforts of Kansas faculty in opposition to this policy and the crafting of the policy itself.
\end{abstract}

Keywords: legal mobilization, rights consciousness, free speech, academic freedom, public employees

\section{Introduction}

\subsection{Introduce the Problem}

On September 16, 2013, David Guth, a tenured associate professor of journalism at the University of Kansas, a research university in the middle of the United States, posted a statement to his Twitter account in reaction to the shootings at the Washington Naval Yard in Washington, D.C., that occurred earlier that day, directing his anger toward the National Rifle Association (NRA). The statement read:

"\#NavyYardShooting The blood is on the hands of the \#NRA. Next time, let it by YOUR sons and daughters. Shame on you. May God damn you."

Within a week, Professor Guth was placed on paid administrative leave by the University of Kansas and several members of the state legislature called for his termination (Celock, 2013).

Three months later, the Kansas Board of Regents (KBOR), the nine-member, governor-appointed, governing body of the state's universities and community and technical colleges, announced plans to amend the KBOR Policy Manual to address the current lack of "provisions specifically dealing with use of social media in a way that respects and protects the rights of individuals to speak freely while also addressing the employee's responsibility to the university and the university's need to operate in an efficient and effective manner...."(Kansas Board of Regents, 2013) A policy was quickly approved by KBOR, with assurances from the state Attorney General and the Board's general counsel that the First Amendment and due process rights of university faculty and other employees was not placed in jeopardy by the policy. ${ }^{1}$

The approved policy authorized the chief executive office of the university to discipline, including the termination of employment, any employee for "improper use of social media," which includes speech that

i. directly incites violence or other immediate breach of the peace; 
ii. when made pursuant to...the employees' official duties, is contrary to the best interests of the University

iii. discloses without authority...[various forms of confidential information]; or

iv. $\quad$ subject to the balancing analysis [stated in the policy]..., impairs discipline by superiors or harmony among coworkers, has a detrimental impact on close working relationships for which personal loyalty and confidence are necessary, impedes the performance of the speaker's official duties, interferes with the regular operation of the university, or otherwise adversely affects the university's ability to efficiently provide services. (Minutes, 2013)

After significant negative feedback on the policy from the media (Cooper, 2013) and the faculty of Kansas educational institutions, (Hoeflich, 2014; Nel, 2014) a working group was formed of faculty and other employees of the Regent institutions to suggest amendments to the recently passed rule. These suggestions varied in tone and content from the KBOR rule; in addition to a statement upholding the importance of academic freedom, the suggested amendments served more as guidelines, recognizing the utility of social media platforms for the academic mission of universities, while reminding faculty and other employees of the responsibilities associated with their professions, citing the 1940 Statement of Principles of the American Association of University Professors (Memorandum, 2014).

Additionally, the working group submitted data and analysis of currently existing policies in other states that relate to the issue of the use of social media. In their analysis, the group noted the extreme rarity of disciplinary policies and suggested that the Board adopt a policy more akin to the policies of other states' university systems, a set of advisory guidelines (Appendix, 2014). While KBOR did ultimately incorporate the working group's language on academic freedom and First Amendment rights, their most important suggestions regarding the disciplinary vs. advisory tone of the policy was ignored. In May of 2014, the Board officially adopted a policy that retained the above enumerated language defining the misuse of social media and authorizing a university's top administrator to discipline and/or terminate the employment of any employee thought to use social media in such a manner. ${ }^{2}$

\subsection{Explore the Importance of the Problem}

The creation and passage of the social media policy in the state of Kansas and the subsequent reaction of faculty at the affected academic institutions raise a number of important points. First, the policy passed by KBOR represents a potential threat to the First Amendment rights and academic freedom of faculty and to the quality of education produced at those institutions. At a time when public education is frequently seen at odds with the political efforts of state legislatures to reduce state spending, all aspects of legislative and executive oversight over public institutions of education take on a heightened importance.

Second, the enacted policy is a matter of legal importance independent of any political efforts aimed at weakening public academics. At the heart of the Social Media Policy is a contested and complex area of constitutional law, the speech rights of public employees. Members of the U.S. Supreme Court have acknowledged that states do have legitimate interests in regulating the speech of its employees (Pickering v. Board of Education, 391 U.S. 563, 568 [1968]); such an authority is an important element of the oversight powers the government has over entities charged with providing public services. Nonetheless, other members have expressed concern over the development of the related case law, especially regarding potential implications for the protection of whistleblowers and public academics (Garcetti v. Ceballos, 547 U.S. 410, 438 [2006] Souter dissenting).

The preceding points raised by the Social Media Policy, namely, the political fight over the role of education and the legal debate over the speech rights of public employees, are important points. Ultimately, this article is less concerned with explaining those points and more concerned with a third point, the relationship between rights consciousness and legal mobilization. A significant result of this enacted policy is the reaction of faculty at affected institutions and their efforts to resist this change in policy. The previous points of policy and law provide a backdrop for this reaction, a backdrop which makes the reaction of faculty all the more important, given the stakes. The passage of the Social Media Policy provides important observations about the manner in which individuals respond to threats to rights. In particular, this article addresses the degree to which formalized rights, rights which have been articulated as the result of past litigation, inform and mobilize actors trying to protect their rights.

\subsection{Describe the Relevant Literature}

While critics exist which would distance the mobilization of political interests from, what they would describe as, 
an impoverishment of discourse through a focus on rights claims (Glendon, 1991), the study of legal mobilization has long been peppered with rights discourse. One of the earliest and most cited definitions of legal mobilization identifies it as "when a desire or want is translated into a demand as an assertion of one's rights" (Zemans, 1983, 700). In a broader sense, the study of legal mobilization covers an area of legal and political life that extends beyond rights claims, focusing, in particular, on various aspects of litigation.

While this article does not focus on litigation in any practiced or anticipated context, the centered spot of litigation in the study of legal mobilization is still worth noting. Approaches and foci within legal mobilization are diverse and researchers in this field understand litigation as part of a complex, multifaceted relationship. Generally, studies of legal mobilization, while focusing on litigation, focus on it as one of multiple avenues of political action, resulting from complex and indeterminate strategic decision-making, and unequally accessible across different levels of society (McCann, 2008, 524-525) For example, studies of legal mobilization may rely heavily on the idea of the dispute pyramid, in which actual litigation is rare in comparison to the amount of claimable grievances (Miller and Sarat 1980), or on the observation that "repeat players" and "one-shotters" have differing levels of legal resources, thus making litigation a far less impactful source of policy change for some (Galanter, 1974). Both of these claims would cast litigation in a limited role in explaining some forms of political mobilization. However, neither could dismiss litigation as irrelevant; in fact, both would have to acknowledge litigation as an important tenet of a larger explanation.

This focus on litigation is, itself, rooted in a more foundational central tenet of legal mobilization, and that is a "bottom-up" or "user theory" approach to the study of law, in which the analytic focus is "on the actions of legal subjects, especially nonofficial legal actors" (McCann, 2008, 523-524). A focus on nonofficial actors makes sense given the disciplines focus on litigation; the reactionary nature of U.S. courts, specifically, limits their ability to actively shape the policy agenda. It is, therefore, through the actions of "private citizens who, in the process of involving legal norms, employ the power of the state and so become state actors themselves" (Zemans, 1983, 692). Additionally, there are different analytical perspectives within the bottom-up focus of legal mobilization. The instrumental view focuses on the way that individuals utilize and mobilize the law as a tool to achieve particular political ends (McCann, 2008, 526). Within this approach, litigation, utilized or not, is the main focus, determining when litigation is used, under what conditions, and whether it is successful in achieving ends. The other perspective from which legal mobilization views the law from its bottom-up direction is the constitutive perspective, which "explores how legal conventions routinely prefigure, delimit, and express the expectations, aspirations, and practical world-views of subjects" (526) Within this approach, the activity of litigation, or even the end result of such litigation, is less relevant than the impact the law has on the participants and, consequently, how such an impact shapes the current and future pursuit of policy goals. "Most scholars take individuals as their starting point, but they recognize that individual consciousness is shaped by the patterns of socially constructed and institutionalized discourses, logics, practices, and relationships in which subjects participate" (529).

Sometimes, the aforementioned discourses and practices consist of actual litigation or negotiations conducted in an environment over which the possibility of litigation hovers. In Rights at Work, McCann observed that women engaged in comparable pay disputes in their workplaces emerged with a sophisticated and critical understanding of not only the elements and values of antidiscrimination law but also the goals and strategies of the movement in which they were involved (1994, 230-232). Likewise, Lovell's research has found that early complainants to the Civil Rights Section of the Justice Department were sometimes able to respond to rejections of their claims with arguments that demonstrated a sophisticated understanding of both constitutional and statutory principles (Lovell, 2006). The important lesson of such observations is that the political role that litigation plays can be seen not only in the outcomes of specific cases, in which a judicial decision shapes policy in a stated manner, but also in the effect of legal institutions on political individuals, effects that alter the political environment and shape political engagement.

The observed effects vary in nature and in kind, which can be seen in Vanhala's scholarship. Her research on the role of litigation in the environmental movement in the United Kingdom focuses on effects that can be more traditionally understood as legalistic. Even in the face of a judicial environment that was less than receptive to the substantive claims made by environmental groups, their litigation produced certain procedural victories, the effect of which were legal and political benefits, making the court more open to their arguments and governments more wary of their claims (2012). Her research on disability rights in Canada, on the other hand, observed effects in the area of consciousness raising around identity politics and the framing of group rights claims (2011). Both situations are examples of legal mobilization in which the outcome of the litigation, in terms of specific rulings, was beside the point; the impact of lawsuits can also be heuristic in nature, shaping meaning 
and understanding of concepts, values, and identities.

This latter focus on an understanding of rights and entitlements, namely, rights consciousness, can be seen in Scheingold's The Politics of Rights, a foundational text in the study of legal mobilization. Scheingold juxtaposed "The Politics of Rights" with "The Myth of Rights." The myth is "premised on a direct linking of litigation, rights, and remedies with social change" $(1974,5)$. The reality of implementing rights is far more complex and less predictable, relying, as implementation always does, on the acquiescence of multiple political institutions. Where rights can be seen having a tangible political impact is through mobilization, "a dual process of activating a quiescent citizenry and organizing groups into effective political units" (131).

Despite the prominence of his articulation of the politics of rights as political mobilization, Scheingold did not dismiss the mythical side of rights as meaningless. "The principle impact of the myth of rights is on cognition and, more specifically, on perceptions of legitimacy.... Belief in the law, acceptance of constitutional values, respect for legal institutions - these all become political facts..." (90-91). Even in their mythical form, influence of rights on political activities has been deemed "incontestable" (92). Through the utilization of rights discourse, political activists have both strategically organized their political activities while activating a consciousness within their members, a consciousness necessary to frame debate and mobilize support. "Its strategic utility enhanced by its cultural resonance, the mobilization of rights thus worked in two directions simultaneously: it provided a relatively conscious platform on which to pursue one's interests and a relatively unconscious, indirect method for perceiving those interests in the first place" (Dudas, 2005, 731).

At this unconscious level, the law, as an institution, plays an important role in the formation of rights and an awareness of those rights. "Law provides individuals with a powerful set of interpretative tools in [the] disputing process. So prevalent in U.S. culture and politics, legal ideas and concepts are an important source of cultural schemas and frames" (Marshall, 2003). But the relationship between the law and a population's expression and understanding of that law is complex. Since the language of the law is accessed by people who are influenced by other cultural constructs in addition to the law, legal claims may deviate from the official language of the law (Ewick \& Silbey, 1998). Therefore, distinguishing the influence of the formal language of law from other, less formal sources of influence is difficult; if an actor claims to be motivated be a sense of her rights, the question remains whether that understanding of rights is rooted in the law as established by courts or in some informal, cultural perception of rights. Despite the difficulties inherent in such a task, attention to the influence of judicial articulations is warranted.

The judicial branch has an important role to play in the articulation and definition of rights. The power of a rights claim comes in its enabling of the speaker or claimant to an entitlement, an interest to which she is entitled, an interest protected against the countering claims of the majority. In this regard, legal mobilization research has long paid special attention to the potential for "the individual citizen (to) be a true participant in the governmental scheme as an enforcer of the law..." (Zemans, 1983). While legislatures are not powerless to establish rights, the courts play an important role in defining rights and have been the source of several important rights in U.S. political history. Such research, however, has also observed "some important limits on the capacity of official law to shape the political consciousness of ordinary people" (Lovell, 2006, 305). An important reason for this limitation is the fact that the law is not self-enforcing; while "judicial opinions....articulate rights...those rights depend heavily on the initiative of ordinary individuals to invoke them-not just in the courtroom, but also in the context of their daily lives" (Marshall, 2005, 119). Those individual initiatives to enforce legal values are frequently confronted by more political concerns and larger institutional interests (Marshall, 2003; Lovell, 2006; Kihnley, 2000).

Nonetheless, the question of whether rights consciousness is mobilized by the actual content of the law, as expressed in judicial rulings and precedent, is still an important question. McCann categorizes the types of contexts in which mobilization occurs into two groups of factors: political opportunities and organizational resources (McCann, 1994, 135). The content of law shapes the political opportunities available to potential litigants, and a knowledge of the law, while not dispositive, would certainly influence the mobilization of a population for or against a particular policy. Here, legal mobilization "implicitly recognizes the central role that mere knowledge and assertion of legal norms have in the distribution of public policy" (Zemans, 1983, 694). Likewise, past rulings can influence how receptive a court is to a particular argument and, even when litigation is not the end goal, the strength of a group's bargaining position or the validity of their claims to entitlement are certainly strengthened by validation from the judiciary.

Consider, for example, Marshall's research on rights consciousness and sexual harassment policies. Her research observes an ineffectiveness of official sexual harassment policies in a university setting and a general avoidance 
of litigation or formal dispute resolution. Despite the avoidance of a venue in which formal rights claims could be put forth, "women who pursued complaints — even at the most informal level—prepared for the process as though they were preparing for litigation. They arranged for witnesses; they preserved incriminating evidence; they kept logs of events to document the incidents, all to prove to a supervisor or other third party that the events actually happened" (Marshall 2005, 118). Even when rights are not used as a formal legal resource, their formal articulation demonstrably shapes engagement of actors engaged in conflict. In this case, a judicial articulation of proof in sexual harassment cases shapes the behavior of complainants, and has the potential to strengthen or weaken such claims and evidence as political resources.

The context of organizational resources makes an awareness of formal legal norms and rules more important. One of the central tenets of legal mobilization is an awareness of the disparate capacity of different citizens to mobilize the law (McCann, 2008, 525). Additionally, research in this field has focused primarily upon the mobilization of law by "the less powerful or marginalized among the unofficial ordinary people in civil society" (524). This focus is justified but paints an incomplete picture. While this focus is able to demonstrate how the law can be used to politically mobilize groups and individuals in informal ways, such mobilization is frequently against forces with greater access to legal resources, resources designed to work with the formalized content of the law. Furthermore, such an articulation of the law, it can be argued, "may work in behalf of change, but its dominant tendency is surely to reinforce the status quo...by legitimating the existing order" (Scheingold, 1974, 91). This imbalance of power can make knowledge of the legal content of rights a valuable resource for activists, raising the question of whether such knowledge is likely to filter down to the population and play a role in their political mobilization.

\subsection{State Hypotheses and Their Correspondence to Research Design}

The inquiry of this article is informed by the preceding review of legal mobilization literature, especially as it relates to the question of rights consciousness. Of particular importance is the literature that considers how law and litigation shape an understanding of rights and entitlements, namely, rights consciousness. The role that rights consciousness plays in the subject of legal mobilization is the possibility that the language and practice of law can shape the perspectives, values, goals, and self-perception and identity of political actors, thus allowing for a broader understanding of legal impact, or how law affects politics. In particular, this article focuses on the formal articulation of law, the results of past litigation in which courts state the presence and content of a right, and the degree to which the formal content of the law affects legal mobilization. Specifically, this article addresses two types of interaction between formally articulated speech rights and the mobilized political response of faculty.

\subsubsection{The Legal Background of the Social Media Policy}

McCann identifies political opportunities as one particular set of factors that shape the context of legal mobilization $(1994,135)$. In the case of the KBOR Social Media Policy, the law is the developed legal doctrine of free speech rights in the context of public employment. The political opportunities created by that body of law are defined by the terrain on which the faculty of Kansas public universities and KBOR interact. The contours of that terrain include the rights that faculty can claim, the authority the state can claim, and the history of past judicial decisions indicating to both parties the degree to which the courts are likely to uphold the claims made by both sides. Therefore, one focus of this article is the identification of the background case law of the speech rights of public employees and an investigation for evidence of that case law shaping the formation of the Social Media Policy and the context of the subsequent debate.

\subsubsection{Faculty Responses to the Social Media Policy}

The second set of factors that shape the context of legal mobilization identified by McCann includes organizational resources $(1994,135)$. In this particular case, such organizational resources include the rights consciousness of faculty members affected by the Social Media Policy. A population that is more aware of its rights is more likely to mobilize in resistance to policies aimed at abrogating those rights. Therefore, this article seeks to identify the content of the rights consciousness of faculty at Kansas state universities and investigate whether that consciousness has been formed through the formal articulation of those rights by the judiciary.

\section{Methods}

This article reviews the developed doctrine of First Amendment free speech rights as they apply to public employees and as detailed by the U.S. Supreme Court. This review highlights principles and phrases developed by the Court that define the boundaries of those speech rights. Those phrases are then used to evaluate the policy-related activities of both KBOR and the faculty employed at universities under that institution's 
jurisdiction.

To determine the influence of the formal law on the behavior of KBOR, the Social Media Policy is analyzed to determine the degree to which an awareness of case law shaped the formation of that policy. Additionally, the content of comments made by faculty in reaction to the Social Media Policy are analyzed. The influence of both case law and other concerns are mapped and correlated to determine whether an informed rights consciousness shaped their opposition to the policy.

After KBOR received its report of the Social Media Workgroup, it incorporated some of the language from the recommendations and proposed a new policy, to be voted upon in the May 2014 meeting. For one month prior to that meeting, KBOR made their proposal available to the public and solicited comments and suggestions from the public. A collection of those comments, with all identifying personal information redacted, serves as the basis of this paper's observations and analysis of faculty opposition to the Social Media Policy.

A total of 180 comments were submitted to KBOR through a system made available on the Board's webpage. It is first worth noting that comments were heavily critical of the policy. Of the total 180 comments, $93.3 \%$ expressed opposition to the KBOR policy. As the focus of this paper is the rights consciousness of those opposing the policy, the small percentage of respondents supporting the policy were eliminated from further analysis.

While KBOR redacted identifying personal information from the comments, some information from the initial form respondents completed remained. This included a line for the respondent to identify his or her affiliated institution. While it may be safe to assume that the vast majority of respondents were affiliated with a Kansas institution, only respondents that could be identified as affiliated with a Regent university or college, either in the initial form or by the content of the comment, were included for further analysis. This left 135 comments, all of which expressed opposition to the Social Media Policy, from respondents identified as affiliated with a Kansas public university. The contents of these comments were then analyzed to determine the nature of faculty opposition to the policy, including the types of concerns held by those individuals and the degree to which the comments were influenced by language and concerns associated with rights consciousness.

\section{Results}

\subsection{The Social Media Policy and U.S. Case Law}

Several contextual elements of the KBOR Social Media Policy are particularly relevant to the issue of formal legal doctrine and its relationship to political opportunities and organizational resources in legal mobilization. First, a dense and complex legal doctrine exists which shaped the crafting of this policy and the negative reactions to it. Making the matter particularly complex is the fact that this issue, in which speech by public employees is restricted, exists at the intersection of free speech law and administrative law. While the Court has generally held that First Amendment speech protections are to be afforded a high level of protection, the Court has also had to grapple with the unique conditions of free speech within public employment. In Pickering $v$. Board of Education (391 U.S. 563 [1968]), Justice Thurgood Marshall reiterated that public employment does not come at the cost of a loss of one's constitutional rights; but at the same time, "the State has interests as an employer in regulating the speech of its employees that differ significantly from those it possesses in connection with regulation of the speech of the citizenry in general" (568). Those interests held by the state-employer are "in promoting the efficiency of the public services it performs through its employees" (568). While recognizing the role that trust, collegiality, and confidence can play in the effective management of a state office and in the decision making process involving proper termination, the Court refused to elevate these interests to a paramount position and, instead, called for the balancing of state interests with free speech protections, instead of the application of a general standard by which to judge such conflicts (569).

Nonetheless, the Court has also consistently held that matters of public concern are frequently, and in fact, more likely to be, matters addressed in conversations by public employees, especially when those employees are professionals likely to be particularly informed about such matters of public interest. Seeing the connection between the speech rights of such publicly employed professionals and the overall level of information held by the democratic electorate, the Court has stated that "it is essential that (such employees) be able to speak freely on such questions without fear of retaliatory dismissal" (Pickering, at 572). The resulting legacy of Pickering, known as Pickering balancing, does emphasize safeguarding the rights of a public employee, as a citizen, to engage in public forms of speech (Connick v. Meyers, 461 U.S. 138, 146 [1983]). Furthermore, efforts to terminate employees whose public speech is deemed by the state-employer to harm the office's interest in effective operations must be justified through a burden placed upon the state (Ranking v. McPherson, 483 U.S. 378,388 [1987]). 
More recent Supreme Court decisions have altered the influence of Pickering balancing in such cases. In 2004, the Court upheld the termination of a police officer who, in his off-duty time, appeared in and sold pornographic videos; however, in this case, the officer took deliberate steps to associate those performances with his role as a police officer employed by a specific police force (City of San Diego v. Roe, 543 U.S. 77 [2004]). While the police department certainly did not make the production of such videos the officer's responsibility, nor were they approved by the department, the possible perception of them as reflecting on the department justified the dismissal of the officer. Garcetti v. Ceballos (547 U.S. 410 [2006]) further reduced the public employee's enjoyment of First Amendment protections when the questioned speech is regarded as connected to her official responsibilities. The Court held "that when public employees make statements pursuant to their official duties, the employees are not speaking as citizens for First Amendment purposes, and the Constitution does not insulate their communications from employer discipline" (421).

The Court justifies such a categorical exemption from First Amendment protections by returning to Pickering and observing that precedent has long recognized that a public employee's speech protections are at their highest when they involve speech made as a citizen on a matter of public concern (418). It is in such situations that state-employers face the onus of demonstrating that, on the balance, the state interest in maintaining a state service outweighs the employee's speech interest. However, when this situation is not met, when the speech in question is not that of a citizen engaged in public discourse, then the state need not engage in Pickering balancing, as the speech is purely of a private nature, such as interpersonal bickering or insults, and can be considered as any type of behavior potentially warranting discipline (Waters v. Churchill, 515 U.S. 661 [1994]). In Garcetti, speech that is part of an employee's official duties is regarded as speech as an employee, as opposed to as a citizen. Speech made in an official capacity is now regarded by the Court as a controlling factor and, as such, "restricting speech that owes its existence to a public employee's professional responsibilities does not infringe any liberties the employee might have enjoyed as a private citizen. It simply reflects the exercise of employer control over what the employer itself has commissioned or created" (421-422).

These rulings form the legal battleground of the KBOR Social Media Policy. In crafting such a policy, KBOR inserted itself within this particular legal issue, the simultaneous recognition of the First Amendment rights enjoyed by citizens, including public employees, and the authority of government agencies to regulate the behavior of its employees in the public interest, a basic principle of administrative law that pursues government accountability. The presence of doctrinal statements by the Supreme Court is not meant to imply that there is a clear rule, applicable to this situation, beyond debate. Clearly the standards of Pickering and Garcetti, in addition to conflicting with each other, do not perfectly mirror the speech regulated by the KBOR policy. Garcetti involves a district attorney, alleging retaliation against him from comments he made criticizing the handling of a search warrant (415). Whereas a rule stating the speech that is a part of an employee's official duties is a legitimate basis for discipline may make some sense in that situation, the application of that rule to a professor at a public university is not clear. Justices Kennedy and Souter, for the majority and dissenting opinions, recognized that difference, and did not extend the ruling in Garcetti to public academia $(425,438)$. Souter elaborated that professors, by the nature of their jobs, which require speaking on matters of public concern (protected by Pickering) as a part of their official duties (exempted by Garcetti), would be in a particularly vexing position (438-439, Souter dissenting).

While the policy passed by KBOR can (and should) be criticized, it is also clear that the policy was written with an eye to established First Amendment jurisprudence. Table 1 outlines how language from the original policy, which was held over for the second version of the policy, was clearly informed by Supreme Court case law. This is especially evident with the policy language dealing with speech that "directly incites violence or other immediate breach of the peace." 
Table 1. Supreme Court precedent in the social media policy

\begin{tabular}{|c|c|}
\hline Social Media Policy Language & Precedent \\
\hline \multirow{2}{*}{ "directly incites violence or other immediate breach of the peace" } & Chaplinsky, 572 \\
\hline & Cohen, 20 \\
\hline "when made pursuant (i.e. in furtherance of) the employee's official duties" & Garcetti, 421 \\
\hline "is contrary to the best interests of the University" & Pickering, 567 \\
\hline $\begin{array}{l}\text { "confidential," "impairs discipline by superiors or harmony among coworkers," "close } \\
\text { working relationships for which personal loyalty and confidence are necessary" }\end{array}$ & Pickering, 570 \\
\hline "balancing analysis" & Pickering \\
\hline $\begin{array}{l}\text { "impedes the performance of the speaker's official duties, interferes with the regular } \\
\text { operation university" }\end{array}$ & Pickering, 572 \\
\hline \multirow{2}{*}{ "shall balance the interest of the university in promoting the efficiency of the public services" } & Pickering, 568 \\
\hline & Garcetti, 417 \\
\hline \multirow{3}{*}{ "the employee's right as a citizen to speak on matters of public concern" } & Pickering, 568 \\
\hline & Connick, 146 \\
\hline & Garcetti, 415 \\
\hline "may consider the employee's position within the university" & Pickering, 582 \\
\hline
\end{tabular}

This refers to the Courts fighting words doctrine, a rule that exempts such speech from First Amendment protection, but was last used to exempt speech in 1942 in Chaplinsky v. New Hampshire (315 U.S. 568 [1942]). The specific language indicating the directness and immediacy of exempted language is specified in subsequent cases (Cohen v. California, 403 U.S. 15 [1971]). The inclusion of that language is important; it establishes a narrow range of speech that can be classified as fighting words and its inclusion in the policy was intended. During the meeting in which the policy was first introduced and passed, the Board's general counsel addressed many of the obvious concerns with the policy, referencing Chaplinsky, Pickering, Garcetti, and other cases (Minutes 2013, 7-9).

This level of specific legal knowledge should not be surprising. As a government panel, they have access to a general counsel and the state attorney general. Furthermore, when the original policy was written and passed, four of the nine members were lawyers. ${ }^{3}$ From the perspective of a critic of the Social Media Policy, this seems to confirm Scheingold's earlier statements about the law and the language of rights mostly working to uphold the power of the status quo $(1974,91)$. This really should not be surprising if one considers the nature of constitutional law. When the Supreme Court decides a constitutional question, they do so in the context of a specific government action, answering whether it violates a specific constitutional provision. This arrangement does much more to explain the boundaries of acceptable governmental behavior than it does to define the expanse of individual rights. Cases like Chaplinsky and Garcetti, in particular, because they identify acceptable restrictions on speech, function as justifications for similar actions. While it may not, therefore, be surprising that the language of rights, as judicially defined, would be used to inform governments that would seek to limit rights, the likelihood of the use of such language by individuals, especially those that are not legal professionals, still needs to be assessed. 
Table 2. Faculty arguments against social media policy

\begin{tabular}{|c|c|c|}
\hline Expressed Concern & & Percentage \\
\hline \multicolumn{3}{|l|}{ Rights-Based } \\
\hline & Violation of Academic Freedom & $37.0 \%$ \\
\hline & Violation of First Amendment / Free Speech & $45.2 \%$ \\
\hline & Violation of Legal Precedent & $3.0 \%$ \\
\hline \multicolumn{3}{|l|}{ Pragmatic Concerns } \\
\hline & Chilling Effect on Teaching / Research & $26.7 \%$ \\
\hline & Damage to Recruitment / Retention & $23.7 \%$ \\
\hline & Damage to Purpose of Education & $31.1 \%$ \\
\hline & Influx of Lawsuits & $11.9 \%$ \\
\hline \multicolumn{3}{|l|}{ Legal Concerns } \\
\hline & Violation of Due Process & $5.9 \%$ \\
\hline & Vague Language (General) & $44.4 \%$ \\
\hline & Directly Incite Violence & $8.1 \%$ \\
\hline & Official Duties & $5.2 \%$ \\
\hline & Best Interests of the University & $29.6 \%$ \\
\hline & Confidentiality & $5.2 \%$ \\
\hline & Harmony Among Coworkers & $21.5 \%$ \\
\hline & Efficiency of Services & $7.4 \%$ \\
\hline
\end{tabular}

$\mathrm{N}=135$

\subsection{Academics Respond to the Kansas Board of Regents}

Table 2 lists the types of concerns raised by faculty against the policy; these concerns can be categorized into rights-based concerns, pragmatic concerns, and legal concerns. The first category of concerns includes rights-based concerns. This includes comments that expressed concern that a particular right was violated. These numbers would initially indicate promise for the idea that the respondents were understanding and articulating their views in the language of rights, with relatively high percentages of respondents stating that the policy was a violation of a general right to free speech, as articulated by the First Amendment (45.2\%) or of a more specific notion of academic freedom (37.0\%). However, while the respondents certainly expressed their views in the language of rights, it does not appear to be an understanding of rights that is influenced by actual case law, with a very small percentage of respondents making any direct or indirect reference to the larger body of free speech doctrine (3.0\%).

Table 3. Typical statements by pragmatic concern-type

\begin{tabular}{|c|c|}
\hline Concern-Type & Typical Statement \\
\hline $\begin{array}{l}\text { Chilling Effect } \\
\text { Teaching/Research }\end{array}$ & $\begin{array}{l}\text { "First, the retention of the disciplinary part of the policy, and the vagueness of the } \\
\text { prohibitions in items (ii) and (iv) of Section 3, by their very nature exert a chilling } \\
\text { effect on free speech and academic freedom." }\end{array}$ \\
\hline $\begin{array}{l}\text { Damage to } \\
\text { Recruitment/Retention }\end{array}$ & $\begin{array}{l}\text { "The environment of Kansas has been a hard sell to these candidates, but KU itself } \\
\text { was a strong sell. I could always argue that KU is a research university where the } \\
\text { faculty member would be supported in the pursuit of a cutting-edge research } \\
\text { agenda.... The social media policy makes it even harder to sell KU to top faculty } \\
\text { candidates. A new faculty member can be disciplined, even terminated for a tweet." }\end{array}$ \\
\hline $\begin{array}{l}\text { Damage to Purpose of } \\
\text { Education }\end{array}$ & $\begin{array}{l}\text { "Loss of academic freedom at the Regents universities will inevitably result in the } \\
\text { diminution of the roles of those institutions in outreach, education and research, at a } \\
\text { time when the state of Kansas can ill afford that decline. The state, the citizens, and } \\
\text { our economy will all be poorly served by the effects of this policy." }\end{array}$ \\
\hline Influx of Lawsuits & $\begin{array}{l}\text { "The policy inevitably will be the object of lawsuits, which, even if KBOR prevails, } \\
\text { undoubtedly will prove very costly and time-consuming." }\end{array}$ \\
\hline
\end{tabular}


Furthermore, respondents also demonstrated a sizeable level of concern over pragmatic matters. These would be concerns that have less to do with abstract concepts of rights and more to do with the tangible effects that such a policy would have on the respondents' everyday life on the job. While the same respondent could have both rights-based and pragmatic concerns over the policy, these pragmatic concerns can be seen as criticizing the policy less for violating specific constitutional principles and more for just being a foolish policy. In particular, respondents expressed concern over the policy's fit with the goals of education $(31.1 \%)$, the possibility of the policy creating a chilling effect on teaching and research (26.7\%), and the possibility that it would make it more difficulty to attract and retain qualified faculty and students to Kansas (23.7\%). Examples of comments reflecting these pragmatic concerns can be found in Table 3. Finally, some respondents expressed concerns of a more general legal nature; particularly, there was substantial concern over the language in the policy seen as vague or overly broad (44.4\%). Of particular concern to respondents was the difficulty in determining the best interests of the university (29.6\%) and harmony among coworkers $(21.5 \%)$.

These descriptive statistics, while an important starting point in an effort to identify the presence of rights consciousness within legally mobilizing groups, are insufficient for identifying whether judicial articulations of rights are a source of influence on such an awareness of rights. A more common method for observing the presence of rights consciousness is the use of interviews with or surveys of participants in a particular act of legal mobilization (McCann, 2008; Marshall, 2003, 2005; Vanhala, 2009). "Drawing on ethnographic and narrative analyses of everyday disputes, contemporary studies of legal consciousness show that how individuals experience law in their ordinary lives is of central importance for understanding law's influence on societal change" (Fleury-Steiner \& Nielsen, 2006, 3).

There is an intuitive justification for a methodology that produces a thick description of the legal consciousness of individuals and groups engaged in legal mobilization. Studies of legal mobilization have focused on the individual, non-professional participants and have developed a constitutive theory of law, in which law consists of both formal and informal/cultural elements. The resulting research has produced valuable knowledge about the role of law and rights in a broad array of social contexts. However, such indeterminacy and breadth produces an epistemological question: "(I)f legality is inherently indeterminate, contingent, and only loosely tethered to official law, how do we define the boundary between law, or legality, and that which is not law?" (McCann, 2006, xviii) Describing the prevalence and frequency of rights language in interviews or freely-made comments does not solve this particular problem. A consciousness of rights may be revealed, but unless respondents indicate a connection between their consciousness and the formal law, no connection to that formal law can be made. "The danger of the decentering project undertaken by many recent scholars is that it eviscerates this connection between indeterminate meanings and the powerful norms articulated and enforced by official institutions that sustain and circumscribe meaning-making by citizens" (McCann, 2006, xx).

This research is aimed at overcoming some of that confusion by connecting an expression of rights consciousness with other held attitudes, including an awareness of the content of formal declarations of speech rights by the Supreme Court. One way to accomplish this is to look for correlations between expressions of rights consciousness and other revealed statements about knowledge, concern, etc. (Li 2010) The particular data does not provide the opportunity to develop detailed demographics of the individual respondents; responses were not structured by any sort of questioning, guidance, or other feature to provide any sort of commonality. However, commenters, being free to express their general dissatisfaction with the social media policy, revealed different types of concerns over the policy. This provides the opportunity to explore for correlations between an expression of rights consciousness with other revealed concerns, some of which can be interpreted as being rooted in formal articulation of those rights. Binary correlations between revealed relevant concerns by respondents are provided in Table 4.

The highest degree of correlation is a positive and significant correlation between comments regarding the language of the policy specifying improper use of social media as speech that incites violence (VIO) and comments that reference similar language about divulging confidential student information (CON). This could be interpreted as evidence of First Amendment case law influencing the rights consciousness of respondents, as these two parts of the policy are arguably the parts most consistent with existing doctrine and posing the fewest problems. A respondent that recognizes the limits on speech established by the Court would likely, in addressing the topic in a comment, address both of those points. For example, one respondent stated, "That the First Amendment does not protect inciting violence or revealing confidential information is beyond question. This aspect of the policy reiterates policies that the KBOR already has in place." However, any conclusion that this correlation indicates a presence of influence by Court doctrine needs to be offset by the extremely low frequency of mentions of violence and confidentiality in the public comments $(8.1 \%$ and $5.2 \%$, respectively). Therefore, it 
appears that while Court doctrine did seem to shape the understanding of rights of some of the respondents, such respondents were low in number.

Table 4. Binary correlations of concerns

\begin{tabular}{|c|c|c|c|c|c|c|c|c|c|}
\hline & & $\mathbf{A F}$ & CON & ED & FS & HAR & INT & VA & VIO \\
\hline Academic & Pearson Correlation & 1 & .097 & $.214^{*}$ & $.259^{* *}$ & .122 & $.174^{*}$ & $.240^{* *}$ & .052 \\
\hline Freedom & Sig. (2-tailed) & & .261 & .013 & .002 & .160 & .043 & .005 & .550 \\
\hline \multicolumn{10}{|l|}{$(\mathbf{A F})$} \\
\hline Confidentiality & Pearson Correlation & .097 & 1 & .131 & -.011 & $.203^{*}$ & $.287^{* *}$ & $.261^{* *}$ & $.785^{* *}$ \\
\hline$(\mathrm{CON})$ & Sig. (2-tailed) & .261 & & .128 & .900 & .018 & .001 & .002 & .000 \\
\hline Education & Pearson Correlation & $.214^{*}$ & .131 & 1 & $-.224^{* *}$ & .038 & .125 & -.021 & .092 \\
\hline (ED) & Sig. (2-tailed) & .013 & .128 & & .009 & .661 & .150 & .805 & .287 \\
\hline Free & Pearson Correlation & $.259^{* *}$ & -.011 & $-.224^{* *}$ & 1 & .032 & .063 & .146 & -.053 \\
\hline Speech & Sig. (2-tailed) & .002 & .900 & .009 & & .708 & .469 & .090 & .543 \\
\hline \multicolumn{10}{|l|}{ (FS) } \\
\hline Harmony & Pearson Correlation & .122 & $.203^{*}$ & .038 & .032 & 1 & $.293^{* *}$ & $.331^{* *}$ & $.240^{* *}$ \\
\hline (HAR) & Sig. (2-tailed) & .160 & .018 & .661 & .708 & & .001 & .000 & .005 \\
\hline Interests & Pearson Correlation & $.174^{*}$ & $.287^{* *}$ & .125 & .063 & $.293^{* *}$ & 1 & $.432^{* *}$ & $.281^{* *}$ \\
\hline (INT) & Sig. (2-tailed) & .043 & .001 & .150 & .469 & .001 & & .000 & .001 \\
\hline Vagueness & Pearson Correlation & $.240^{* *}$ & $.261^{* *}$ & -.021 & .146 & $.331^{* *}$ & $.432^{* *}$ & 1 & $.224^{* *}$ \\
\hline (VA) & Sig. (2-tailed) & .005 & .002 & .805 & .090 & .000 & .000 & & .009 \\
\hline Violence & Pearson Correlation & .052 & $.785^{* *}$ & .092 & -.053 & $.240^{* *}$ & $.281^{* *}$ & $.224^{* *}$ & 1 \\
\hline (VIO) & Sig. (2-tailed) & .550 & .000 & .287 & .543 & .005 & .001 & .009 & \\
\hline \multicolumn{10}{|l|}{$\mathrm{N}=135$} \\
\hline \multicolumn{10}{|c|}{ *. Correlation is significant at the 0.05 level (2-tailed). } \\
\hline$* *$. Correlation & is significant at the 0.0 & 01 leve & 1 (2-taile & & & & & & \\
\hline
\end{tabular}

Another area of interesting correlation can be seen between concerns over free speech (FS) and academic freedom (AF) with statements about the function and importance of education in society (ED). Statements of concern about free speech were more common than statements about academic freedom, but both were common (45.2\% and $37.0 \%$, respectively). There was also a significant yet low positive correlation between the two, indicating that some respondents did not see much difference between the two terms. However, the relationship that these two variables demonstrate with the education variable does warrant reconsideration of that statement. Comments about academic freedom had a low but significant positive correlation with comments about education, while comments about free speech had a low but significant negative correlation with comments about education. This is an interesting set of correlations if free speech is understood as an abstract right and academic freedom is understood as a pragmatic standard ensuring educational benefits, the implication being that those who saw this policy as a threat to academic freedom were motivated by concerns involving their roles as educators, whereas those who perceived threats to their free speech rights were motivated by rights consciousness. 
While respondents were clearly motivated by a concept of rights, understood either as free speech or academic freedom, the question still remains whether the articulation of those rights by the judiciary has influenced that understanding of rights. As indicated in Table 2, nearly half of all faculty respondents in opposition to the policy referred to the policy as vague (VA). There were varying levels of significant positive correlation between these comments and more specific comments about the policy language; in particular, comments about vagueness were most strongly correlated with concerns over the phrase "best interests of the University" (INT) followed by concerns over the phrase "harmony among coworkers" (HAR).

These are elements of the policy that are vague and troubling and potentially unconstitutional. While the Supreme Court has established that the speech rights of public employees are conditioned by such interests of the state, the Court has also narrowed those state interests. For example, for the state to successful place harmony among coworkers above the free speech rights of an employee, a directness requirement, as in the fighting words doctrine, must be satisfied, and proscribed speech must be "directed towards any person with whom appellant would normally be in contact in the course of his daily work..." (Pickering, 569-570). Furthermore, the Court has limited the state's claims of public interests by countering that "the public interest in having free and unhindered debate on matters of public importance - the core value of the Free Speech Clause of the First Amendment-is so great" (573).

Nonetheless, three factors indicate that such concern over the vagueness of the policy language is not motivated or informed by Court doctrine. First, reference to precedent was exceptionally rare in the comments $(3.0 \%)$, and those that did reference precedent were no more likely $(40 \%)$ to express their concerns in terms of vagueness than the overall body of respondents (44.4\%). Second, comments about vagueness were also significantly correlated positively, albeit at lower levels, with comments about policy language to which the Court has established clearer guiding precedent, namely, the language involving incitements to violence and divulging of confidential information. Finally, comments about vagueness were significantly and positively correlated with comments about academic freedom; no significant correlation could be observed between comments about vagueness and comments about free speech or the First Amendment. This would indicate that concerns over vagueness were more motivated by the pragmatic concerns of faculty than by the principles of rights.

\section{Discussion}

The Social Media Policy currently in effect at all colleges and universities under the Kansas Board of Regents presents something of a paradox. It is a policy that threatens academic freedom and free speech while meticulously abiding by the letter of the law. That such protections were endangered by the policy was a nearly universal perception held by those faculty that responded to the Board's request for feedback; however, that feedback seem to demonstrate little to no awareness of formal principles of speech protection for public employees. At one level, this observation is a bit beside the point. Recall that pragmatic concerns, such as the possibility of a chilling effect on the practice of education, where faculty simply watch and limit what they say, regardless of whether such speech would fall outside the bounds of protection or not, were common concerns. Even if the policy language is consistent with First Amendment principles, implementation of the policy, as opposed to the policy itself, could prove a larger threat to academic freedom. As one respondent said, "The possibility that a faculty member might be able to sue the university and, eventually, win, after years and huge expense, hardly amounts to a protection of their academic freedom." That disconnect between the imagined boundaries of academic speech held by members of KBOR and the universities' faculty provides the basis of a number of discussion points.

The reliance of the policy on the formal principles of the judicially developed doctrine of public employees' speech rights produces two points for consideration. First, it is important to remember that the KBOR policy was heavily influenced by actual Supreme Court doctrine; in fact, the influence of cases like Pickering, which overturned a restriction on speech, was more common than cases that upheld such restrictions, such as Garcetti. Even being critical of the policy, this reliance on legal principles should not be surprising, if one considers the nature of constitutional law. When the Supreme Court adjudicates a constitutional question, they are answering whether a particular action of the government violates a particular constitutional provision. As the U.S. Supreme Court does not issue advisory opinions, opinions are generally limited to whether a violation occurred. The resulting case law functions less as a declaration of what rights persons have and more as a definition of what boundaries the government must obey. Add to that the high likelihood that governmental policy makers will have access to the advice of legal counsel, and constitutional case law will likely be an important building block of policies that abut protected constitutional matters.

Second, the almost unanimous backlash by faculty against the policy, as based upon constitutional principles as 
it was, raises questions about the effectiveness of such case law as a guide for the formation of policy. Although, as stated above, judicial opinions within constitutional law naturally function as a guide for governmental behavior, one must ask whether, in practice, it serves well in that capacity. In this situation, the Board's reliance on legal language did not ease the concerns of faculty; nearly half of all respondents referred to the text of the policy as vague or confusing. For example, the policy language on the incitement of violence was written in a manner to reflect a fighting words doctrine that has been historically applied in a manner deferential to speech rights (Cohen [1971]). The general counsel and state attorney general likely knew the exact significance of each word in the phrase "directed to inciting or producing imminent violence" (Kansas Board of Regents Policy Manual, Chapter II, Section F.6b.3i). That faculty generally were not aware of this information makes this a poorly communicated policy. That university presidents, the officials authorized to terminate faculty for speech made consistent with those legal criteria, also would likely not be aware of this information makes this a dangerous policy.

The nature of the faculty response to the Social Media Policy also raises important points for discussion. Observations of public comments made by faculty at Kansas public universities and colleges about the Social Media Policy passed by the Kansas Board of Regents indicate that, while motivated by a concept of free speech and First Amendment rights, that motivation was not particularly informed by the articulation and definition of those rights as stated by case law from the U.S. Supreme Court. A potential criticism of this conclusion is that it does not really tell us much. First, rights consciousness still exists and the language of rights is still present in the political mobilization observed; it just happens to be a rights language that is not an accurate reflection of those rights legally defined. Such a claim would be accurate. The results of this study do not diminish the role of legal mobilization in pursuit of political change. The results do, however, emphasize that the content of legal decisions, or even whether a lawsuit produces a victory, are not necessarily the most important goals of groups mobilized around the law. Legal actions, from lawsuits to public claims of rights, can serve a number of political purposes, including raising the profile of an issue, galvanization of public opinion, encouraging action from other levels of government, and mobilization of a political organization (Wilkerson, 2010).

Second, one might argue that this research does not tell us much because the results are to be expected. Not only is the observation that people are not thoroughly informed about the content of Supreme Court decisions not particularly surprising, but it could even be seen as condescending, as placing a higher premium on the knowledge of legal professionals than other individuals. Such a reaction would befit the discipline of legal mobilization with its traditional focus on the utilization of law by non-professionals and marginalized populations (McCann 2008, 523-524). However, the attention on formal rights content was not based on a view of such language as superior to non-professional legal language, but on an inquiry into the impact of such language. That observation is more relevant given the status of university faculty as, by definition, having greater access to the resource of education than the general population. In other words, that a highly educated, professional population was not particularly influenced by the formal language of law tells us something about the role that other variables play in situations in which judicial decisions affect policy. Clearly, had the population of professors been replaced with a population of lawyers or law school professors, one would expect a higher reliance on case law. Future observations could include a distinction between unionized and non-unionized faculty, given the legal resources available to unionized faculty.

The results of this research have important implications for the use of rights language in activism. Earlier discussion about the language of rights working to uphold the power of the status quo (Scheingold 1974, 91) seems consistent with these observations. As stated above, KBOR justified this policy under Garcetti, a decision that authorized the restriction of a public employee's freedom of speech. But the language they used came predominantly from Pickering, a case in which the government was found to have violated those rights. The language of rights can be used by those that would restrict rights (Dudas 2005); in fact, the language of rights being formed by decisions of constitutional law is a language of the extent of governmental power. The KBOR Social Media Policy demonstrates that the official and formal language of rights, used by a government entity to justify restrictions on the exercise of a protected right, such as speech, may be a more accurate reflection of the actual law than the rights as they are perceived by their holders. This does not require an abandonment by mobilized politics of efforts to shape those rights through litigation. However, the Social Media Policy instituted by KBOR and the subsequent reaction by affected faculty highlight the multiple layers of rights language, formal and informal, and encourages the critical and judicious use of rights language in mobilization efforts.

\section{Acknowledgements}

An earlier version of this article was presented at the 2015 Meeting of the Law and Society Association. I would like to thank Anne Revillard of the Paris Institute of Political Studies and Anna-Maria Marshall of the University 
of Illinois, Urbana-Champaign, for their informal yet helpful feedback. I would also like to thank the Department of History, Philosophy, and Social Sciences for their financial support in meeting publication costs.

\section{References}

Appendix. (2014). Report of the Kansas Board of Regents Work Group on Social Media Policy, April 8.

Celock, J. (2013). David Guth, Kansas Professor, On Leave After Controversial Tweet—But GOP Lawmakers Want Him Fired. Huffington Post, September 20.

Dudas, J. R. (2005, December). In the Name of Equal Rights: 'Special' Rights and the Politics of Resentment in Post-Civil Rights America. Law and Society Review, 39(4). http://dx.doi.org/10.1111/j.1540-5893.2005.00243.x

Ewick, P., \& Silbey, S. S. (1998). The Common Place of Law: Stories From Everyday Life. Chicago: University of Chicago Press.

Fleury-Steiner, B., \& Nielsen, L. B. (2006). A Constitutive Perspective of Rights. In B. Fleury-Steiner, \& L. B. Nielsen (Eds.), The New Civil Rights Research: A Constitutive Approach. Burlington: Ashgate Publishers.

Galanter, M. (1974). Why the 'Haves' Come out Ahead: Speculations on the Limits of Legal Change. Law and Society Review, 9(1). http://dx.doi.org/10.2307/3053023

Glendon, M. A. (1991). Rights Talk: The Impoverishment of Political Discourse. New York: The Free Press.

Hoeflich, M. (2014, January 8). Opinion: Regents' Policy has a Silver Lining. Lawrence Journal World.

Kansas Board of Regents. (2013, December 18). Board Amends Policy to Include Language Regarding Improper Use of Social Media.

Kihnley, J. (2000). Unraveling the Ivory Fabric: Institutional Obstacles to the Handling of Sexual Harassment Complaints. Law and Social Inquiry, 25. http://dx.doi.org/10.1111/j.1747-4469.2000.tb00151.x

Li, L. J. (2010, July). Rights Consciousness and Rules Consciousness in Contemporary China. The China Journal, (64).

Lovell, G. I. (2006). Justice Excused: The Deployment of Law in Everyday Political Encounters. Law and Society Review, 40(2), 305-307. http://dx.doi.org/10.1111/j.1540-5893.2006.00265.x

Marshall, A.-M. (2003). Injustice Frames, Legality, and the Everyday Construction of Sexual Harassment. Law and Social Inquiry, 28, 661. http://dx.doi.org/10.1111/j.1747-4469.2003.tb00211.x

Marshall, A.-M. (2005). Idle Rights: Employee's Rights Consciousness and the Construction of Sexual $\begin{array}{llllll}\text { Harassment Policy. Law and Society } & \text { Review, } & 39(1), & 119 .\end{array}$ http://dx.doi.org/10.1111/j.0023-9216.2005.00078.x

McCann, M. (1994). Rights at Work: Pay Equity Reform and the Politics of Legal Mobilization. Chicago: University of Chicago Press. http://dx.doi.org/10.1093/oxfordhb/9780199208425.003.0030

McCann, M. (2006). On Legal Rights Consciousness: A Challenging Analytical Tradition. In B. Fleury-Steiner, \& L. B. Nielsen (Eds.), The New Civil Rights Research: A Constitutive Approach. Burlington: Ashgate Publishers.

McCann, M. (2008). Litigation and Legal Mobilization. In K. E. Whittington, R. D. Kelemen, \& G. A. Caldeira (Eds.), The Oxford Handbook of Law and Politics. New York: Oxford University Press.

Memorandum. (2014). To Kansas Board of Regents, From Social Media Workgroup. April 8, 2014. Minutes, Meeting of the Kansas Board of Regents, May 14-15.

Miller, R. E., \& Sarat, A. (1980). Grievances, Claims, and Disputes: Assessing the Adversary Culture. Law and Society Review, 15(3-4). http://dx.doi.org/10.2307/3053502

Minutes, Meeting of the Kansas Board of Regents, December 18-19, 2013.

Minutes, Meeting of the Kansas Board of Regents, May 14-15, 2014.

Nel, P. (2014, January 7). Opinion: KSU Prof Weighs in on Social Media Policy. Lawrence Journal World.

Scheingold, S. (1974). The Politics of Rights: Lawyers, Public Policy, and Political Change. New Haven: Yale University Press.

Vanhala, L. (2011). Making Rights a Reality? Disability Rights Activists and Legal Mobilization. New York: Cambridge University Press. 
Vanhala, L. (2012). Legal Opportunity Structures and the Paradox of Legal Mobilization by the Environmental Movement in the UK. Law and Society Review, 46(3). http://dx.doi.org/10.1111/j.1540-5893.2012.00505.x

Wilkerson, W. R. (2010). Kelo v. New London, the Institute for Justice, and the Idea of Economic Development Takings. In W. V. McIntosh, \& L. Hatcher (Eds.), Property Rights and Neoliberalism: Cultural Demands and Legal Actions. Surrey: Ashgate Publishers.

Zemans, F. K. (1983, September). Legal Mobilization: The Neglected Role of Law in the Political System. The American Political Science Review, 77(3). http://dx.doi.org/10.2307/1957268

\section{References (United States Supreme Court Opinions)}

Chaplinsky v. New Hampshire, 315 U.S. 568 (1942)

City of San Diego v. Roe, 543 U.S. 77 (2004)

Cohen v. California, 403 U.S. 15 (1971)

Connick v. Myers, 461 U.S. 138, 146 (1983)

Garcetti v. Ceballos, 547 U.S. 410 (2006)

Grutter v. Bollinger, 539 U.S. 306, 329 (2003)

Pickering v. Board of Education, 391 U.S. 563 (1968)

Rankin v. McPherson, 483 U.S. 378, 388 (1987)

Waters v. Churchill, 515 U.S. 661 (1994)

\section{Notes}

Note 1. The original Social Media Policy can be found, in its entirety, on pages 9-11 of the Minutes of the Kansas Board of Regents meeting from December 18-19, 2013, available at http://www.kansasregents.org/resources/PDF/2799-LDec18-19,2013Minutes.pdf

Note 2. The finalized Social Media Policy can be found, in its entirely, on pages 6-8 of the Minutes of the Kansas Board of Regents meeting from May 14-15, 2014, available at http://www.kansasregents.org/resources/PDF/E_May_14-15_2014_Minutes.pdf

Note 3. Members of the Kansas Board of Regents in December of 2013 that possessed a J.D. include Fred Logan (Chair), Shane Bangerter, Tim Emert, and Robba Moran.

\section{Copyrights}

Copyright for this article is retained by the author(s), with first publication rights granted to the journal.

This is an open-access article distributed under the terms and conditions of the Creative Commons Attribution license (http://creativecommons.org/licenses/by/3.0/). 